\title{
MENGEMBANGKAN POTENSI DESA DENGAN PENINGKATAN KESEHATAN DAN KREATIVITAS MASYARAKAT
}

\author{
Ramon Syahrial \\ Universitas Wijaya Putra Surabaya \\ Ramonsyahrial@uwp.ac.ad
}

\begin{abstract}
Abstrak
Dalam Pasal 3 Undang-Undang Nomor 36 Tahun 2009 tentang Kesehatan menyatakan pembangunan kesehatan bertujuan untuk meningkatkan kesadaran, kemauan, dan kemampuan hidup sehat bagi setiap orang agar terwujud derajat kesehatan masyarakat yang setinggi-tingginya, sebagai investasi bagi pembangunan sumber daya manusia yang produktif secara sosial dan ekonomis. Berdasar dari undang-undang diatas Program pengabdian kepada masyarakat yang dilaksanakan di desa Bendungan, Kelurahan Sumur Welut, Kecamatan Lakarsantri, Surabaya adalah (1) Meningkatkan kesadaran masyarakat terhadap kesehatan khususnya kesehatan diri, Di Desa Bendungan ini mayoritas masyarakatnya adalah para Petani. Dan mereka sering tidak memperdulikan akan kondisi tubuhnya, karena kebanyakan penduduk desa meyakini bahwa jika tidak ada rasa sakit maka tidak perlu diperiksa akan kesehatannya. (2) Menciptakan masyarakat desa yang kreatif sehingga mampu berinovasi dengan sumber daya yang tersedia, (3) Secara bertahap membantu menjadikan Desa Bendungan sebagai salah satu destinasi wisata pada wilayah kota yang bertujuan untuk meningkatkan perekonomian dan kesejahteraan.

Dalam pengabdian kepada masyarakat ini agar rencana program dapat terlaksana dan berkelanjutan adalah dengan mengoptimalkan sumber daya yang ada di desa Bendungan dengan melibatkan seluruh unsur-unsur masyarakat yang ada. Sehingga program yang direncanakan, yaitu dengan meningkatkan kesehatan masyarakat dan kreativitasnya sebagai salah satu media dalam mengembangkaan potensi desa semakin cepat terlaksana. Program kesehatan dilaksanakan secara terjadwal dengan melakukan sosialisasi berkaitan kesehatan dan pentingnya kesehatan, sedangkan program kreativitas dilaksanakan dengan memberikan beberapa pelatihan dan ketrampilan yang menunjang potensi desa.
\end{abstract}

Kata kunci: Kesehatan, Kreativitas, Potensi Desa

\section{PENDAHULUAN}

Kesehatan memiliki peranan penting guna meningkatkan kualitas masyarakat agar mampu dalam meningkatkan kesadaran, kemauan, dan kemampuan hidup sebagai investasi bagi pembangunan sumber daya manusia yang produktif secara sosial dan ekonomi serta sebagai salah satu unsur kesejahteraan umum sebagaimana dimaksud dalam Pembukaan Undang-Undang Dasar Negara Republik Indonesia Tahun 1945.

Dalam Pasal 3 Undang-Undang Nomor 36 Tahun 2009 tentang Kesehatan menyatakan pembangunan kesehatan bertujuan untuk 
meningkatkan kesadaran, kemauan, dan kemampuan hidup sehat bagi setiap orang agar terwujud derajat kesehatan masyarakat yang setinggi-tingginya, sebagai investasi bagi pembangunan sumber daya manusia yang produktif secara sosial dan ekonomis. Pembangunan kesehatan yang sedang dilaksanakan masih menghadapi berbagai masalah yang belum sepenuhnya dapat diatasi, sehingga diperlukan pemantapan dan percepatan melalui berbagai program dan kegiatan. Salah satu kegiatan pada Deputi Bidang Pengembangan Sumber Daya, Kementerian Pembangunan Daerah Tertinggal untuk meningkatkan derajat kesehatan di daerah tertinggal adalah Kegiatan Perdesaan Sehat.

Di Desa Bendungan, Kelurahan Sumur Welut, Kecamatan Lakarsantri, Surabaya, mayoritas masyarakatnya adalah para Petani. Dan dari wawancara dengan beberapa masyarakat di desa tersebut mereka sering tidak memperdulikan akan kondisi tubuhnya, karena kebanyakan penduduk desa meyakini bahwa jika tidak ada rasa sakit maka tidak perlu diperiksa akan kesehatannya. Sebagai desa yang mempunyai potensi wilayah yang menjajikan sebagai obyek wisata di wilayah Surabaya Barat harus ditunjang terlebih dahulu dengan kesadaran tentang kesehatan masyarakat desa tersebut. Sehingga bagaimana menumbuhkan kepedulian masyarakat di Desa Bendungan tentang kesehatan, baik kesehatan lingkungan maupun kesehatan dirinya sebagai seorang petani.

Pengembangan suatu wilayah pedesaansesuai dengan amanah Undang-undang No.6 Tahun 2014 tentang Desa dan peraturan pelaksananya. Otonomi desa dimaknai sebagai adanya kemampuan serta prakarsa masyarakat desa untuk dapat mengatur dan melaksanakan dinamika kehidupannya dengan didasarkan pada kemampuannya sendiri. Hal ini berarti bahwa intervensi dari luar desa harus dikurangi dan sifat otonomi desa adalah merupakan otonomi murni, artinya keberadaan otonomi desa merupakan sesuatu yang memang telah ada sejak desa itu mulai ada, dan bukan merupakan sebuah limpahan wewenang dari negara (Nadir, 2013: 89). Otonomi desa bukan sebuah kedaulatan melainkan pengakuan adanya hak untuk menggatur urusan rumah tangganya sendiri dengan dasar prakarsa dari masyarakat. Otonomi dengan sendirinya dapat menutup pintu intervensi institusi diatasnya dan sebaliknya tidak dibenarkan proses intervensi yang serba paksa, mendadak dan tidak melihat realitas komunitas masyarakat desa (Juliantara, 2003: 181). Dari pernyataan inilah masyarakat desa dituntut untuk mampu meningkatkan potensi sumber daya yang ada sesuai dengan kemampuan masyarakat yang ada di desa tersebut

Peningkatan potensi sumber daya yang ada dalam pedesaan tidak akan lepas dari potensi sumber daya manusia yang kreatif, sehingga 
dibutuhkan tambahan wawasan dan pelatihan akan dapat menumbuhkan kreatifitas sumber daya manusia yang ada di desa tersebut.

Diharapkan dengan pengembangan potensi desa di Desa Bendungan, Kelurahan Sumur Welut, Kecamatan Lakarsantri, Surabayaadalah dapat meningkatkan kesejahteraan masyarakat Desa dan kualitas hidup manusia serta meningkatkan taraf hidup melalui pemenuhan kebutuhan dasar dalam bentuk kesehatan, pembangunan sarana dan prasarana desa, pengembangan potensi ekonomi lokal, serta pemanfaatan sumber daya alam dan lingkungan secara berkelanjutan. Salah satu pemberdayaan yang dilakukan saat ini adalah pembangunan desa wisata berbasis budaya, education dan pertanian.

Salah satu daya tarik di Desa Bendungan, Kelurahan Sumur Welut, Kecamatan Lakarsantri, Surabaya merupakan wilayah pedesaan yang berada di kota Surabaya, dan potensi yang bisa ditawarkan sebagai destinasi wisata adalah keaslian baik dari segi sosial budaya (tata cara dan tradisi yang berlaku/ nilai-nilai kearifan lokal), adat istiadat, sebagai tempat edukasi dan hutan kota. Desa Bendungan, Kelurahan Sumur Welut, Kecamatan Lakarsantri, Surabaya memiliki potensi wisata yang berkaitan dengan wisata dan edukasi di bidang pertanian dan pariwisata dalam bentuk hutan. Namun, persoalan yang mendasar terkait dengan pengembangan potensi desa sebagai desa wisata, meliputi: (1) bagaimana mewujudkan desa wisata; (2) bagaimana mempersipakan lingkungan desa dan sumber daya manusia yang ada untuk mampu mewujudkan Desa Bendungan, Kelurahan Sumur Welut, Kecamatan Lakarsantri, Surabaya sebagai desa wisata yang bernilai ekonomi tinggi.

Berdasarkan latar belakang masalah diatas, rumusan masalah dalam program pengabdian ini sebagai berikut(1) Meningkatkan kesadaran masyarakat terhadap kesehatan khususnya kesehatan diri, Di Desa Bendungan ini mayoritas masyarakatnya adalah para Petani. Dan mereka sering tidak memperdulikan akan kondisi tubuhnya, karena kebanyakan penduduk desa meyakini bahwa jika tidak ada rasa sakit maka tidak perlu diperiksa akan kesehatannya. (2) Menciptakan masyarakat desa yang kreatif sehingga mampu berinovasi dengan sumber daya yang tersedia, (3) Secara bertahap membantu menjadikan Desa Bendungan sebagai salah satu destinasi wisata pada wilayah kota yang bertujuan untuk meningkatkan perekonomian dan kesejahteraan.

\section{METODE PELAKSANAAN}

Pengabdian kepada masyarakat dilaksanakan Desa Bendungan, Kelurahan Sumur Welut, Kecamatan Lakarsantri, Surabaya. Metode peningkatan kualitas SDM yang dilaksanakan adalah Meningkatkan kesadaran masyarakat petani terhadap kesehatan khususnya kesehatan diri dan kesehatan lingkungan serta Menciptakan masyarakat desa yang kreatif 
sehingga mampu berinovasi dengan sumber daya yang tersedia dengan memberikan pelatihan dan pendampingan.

Pendekatan pemberdayaan (partisipasi aktif) ini berprinsip pada kemandirian masyarakat, metode ini bertujuan untuk menggali potensi dan meningkatkan kapasitas masyarakat dengan tujuan menguatkan perekonomian lokal. Secara teori suatu pengembangan desa wisata semestinya melaksanakan pendekatan community based tourism yang artinya peran masyarakat dilokasi dimana wisata itu ada sebagai penyedia jasa desa wisata. Pengabdian kepada masyarakat dilakukan dengan beberapa metode, yaitu:

1. Survei

a. Survei pertama dilakukan dalam pengabdian kepada masyarakat di Desa Bendungan, Kelurahan Sumur Welut, Kecamatan Lakarsantri, Surabaya, dilaksanakan bersama masyarakat guna melihat secara langsung kebersihan lingkungan yang ada serta melakukan wawancara dengan masyarakat berkaitan dengan kepedulian akan kesehatan diri masyarakat

b. Survey kedua dilakukan dalam pengabdian kepada masyarakat di Desa Bendungan, Kelurahan Sumur Welut, Kecamatan Lakarsantri, Surabaya, tentang potensi desa yang yang hendak dikembangkan sebagai desa wisata, survei dilakukan untuk melakukan pemetaan potensi desa wisata yang menarik, baik wisata berbasis budaya, education dan pertanian. Dalam survei juga dilakukan wawancara dengan masyarakat.

2. Pelatihan

a. Metode pelatihan berkaitan dengan kesadaran tentang kesehatan dilakukan guna mengedukasi masyarakat berkaitan dengan pentingnya kesehatan lingkungan dan menjaga kesehatan untuk mencegah dan mengetahui lebih dini tentang penyakit dengan gejalanya. Program-program berkaitan dengan kesehatan dilakukan dengan menyelenggarakan penyuluhan dan diskusi serta pemeriksaan kesehatan yang bekerjasama dengan salah satu STIKES di Surabaya

b. Metode pelatihan berkaitan dengan menumbuhkan kreatifitas masyarakat di Desa Bendungan, Kelurahan Sumur Welut, Kecamatan Lakarsantri, Surabaya adalah dengan sarasehan dan diskusi untuk mengetahui potensi masyarakat baik individu maupun kelompok yang selama ini telah dan pernah dilakukan sehingga harapannya pengabdian yang dilakukan mengurangi persoalan tentang kreatifitas masyarakat terhadap potensi yang selama ini Kesehatan 526 
menjadi masalah dalam proses pengembangannya.

Pada dasarnya program-program pelatihan dalam pengabdian masyarakat di Desa Bendungan, Kelurahan Sumur Welut, Kecamatan Lakarsantri, Surabayadikembangkan dengansangat sederhana, yaitu dalam sarasehan dan diskusi santai/ informal sehingga masyarakat tidak terlaluberat dalam menerima materi-materi pelatihan.

Materi-materi pelatihan yang disampaikan mengambil beberapa kasus dan best practice pengelolaan desa wisata, sehingga peserta pelatihan akan memperoleh gambaran-gambaran kasus dan strategi yang seharusnya dilakukan. Selain itu, masyarakat di Desa Bendungan, Kelurahan Sumur Welut, Kecamatan Lakarsantri, Surabayadiberikan kesempatan untuk sharing pengalaman untuk dapatmeningkatkan kreativitas masyarakat dan menjadi penentu pelaksanaan kegiatan dalam menciptakan masyarakat yang mandiri kompetitif berdaya saing (Widjajanti, 2011:25).

3. Pendampingan

Untuk memastikan bahwa programprogram pelatihan dapat berkelanjutan, juga melakukan kegiatan pendampingan dan evaluasi secara rutin. Pedampingan dilakukan untuk melihat perkembangan pelaksanaan dan hambatan-hambatan yang muncul. Dalam prosespendampingan ini, secara maksimal pengabdian kepada masyarakat ini juga memberikan solusisolusi atas hambatan yang dihadapi oleh masyarakat. Pendampingan ini dilakukan agar program dapat terlaksana dengan baik sesuai dengan penerapan hasil pelatihan yang dilakukan. 


\begin{tabular}{|c|c|c|}
\hline \multirow{3}{*}{$\stackrel{\longleftarrow}{\longleftarrow}$} & METODE & \\
\hline & $\downarrow$ & $\rightarrow$ \\
\hline & PELATIHAN & PENDAMPINGAN \\
\hline$\downarrow$ & $\downarrow$ & $\downarrow$ \\
\hline $\begin{array}{l}\text { Teknik: } \\
\text { Observasi dan Wawancara }\end{array}$ & $\begin{array}{l}\text { Teknik: } \\
\text { Presentasi, Studi } \\
\text { Kasus dan diskusi }\end{array}$ & $\begin{array}{l}\text { Teknik: } \\
\text { Pemeriksaan kesehatan } \\
\text { secara gratis dan praktek } \\
\text { bersama }\end{array}$ \\
\hline$\downarrow$ & $\downarrow$ & $\downarrow$ \\
\hline $\begin{array}{l}\text { Target: } \\
\text { - Masyarakat sadar akan } \\
\text { kesehatan dirinya } \\
\text { - Menemukan potensi desa } \\
\text { dan berkreasi }\end{array}$ & $\begin{array}{l}\text { Target: } \\
\text { - Pemahaman } \\
\text { pentingnya } \\
\text { kesehatan } \\
\text { - Pemahaman } \\
\text { tentang } \\
\text { peningkatan } \\
\text { potensi desa } \\
\text { sebagai desa } \\
\text { wisata }\end{array}$ & $\begin{array}{l}\text { Target: } \\
\text { Masyarakat mampu, } \\
\text { paham dan } \\
\text { mengaplikasikan } \\
\text { bagaimana } \\
\text { meningkatkan potensi } \\
\text { desa mereka }\end{array}$ \\
\hline
\end{tabular}

\section{HASILDANPEMBAHASAN}

\section{PotensiDesa}

Potensi suatu wilayah atau suatu desa tidak akan bisa terlepas dari bagaimana pihak dari desa tersebut melaksanakan pemberdayaan masyarakat desa mereka. Pemberdayaan masyarakat adalah suatu proses yang dilakukan oleh masyarakat secara mandiri dalam meningkatkan kesejahteraannya, tidak terkecuali di Desa Bendungan, Kelurahan Sumur Welut, Kecamatan Lakarsantri, Surabaya, yang berkeinginan meningkatkan kesejahteraan masyarakatnya dengan meningkatkan potensi desanya menjadi desa wisata berbasis budaya, education dan pertanian. Dalam proses ini akan melibatkan pihakpihak terkait (Kepala Dusun, Kelompok
Tani dan masyarakat lain), pengembangan potensi suatu wilayah dalam hal potensi dari suatu desa tidak akan bisa lepas dari peran serta masyarakat desa tersebut. Masyarakat desa sebagai pemeran utama dan penentu pembangunan dan penetapan potensi desa wisata, baik proses pembangunan, atraksi yang bisa disuguhkan, akomodasi , fasilitasi desa wisata, kelembagaan pariwisata, promosi dan komunikasi pemasaran, serta usaha berbasis masyarakat yang menjadi ciri khas desa. Ide serta usulan masyarakat merupakan pondasi yang mendasar bagi program pembangunan desa wisata. Yang tidak kalah pentingnya bahwa suatu program perberdayaan masyarakat adalah: program yang disusun sendiri oleh 
masyarakat desa, mampu menjawab kebutuhan dasar masyarakat, keterlibatan, berbasis sumberdaya lokal, penguatan nilai-nilai budaya setempat, memperhatikan dampak lingkungan, menghilangkan ketergantungan, semua elemen masyarakat terlibat, serta terus berinovasi guna keberkelanjutan sebagai desa wisata.

Potensi Desa Bendungan, Kelurahan Sumur Welut, Kecamatan Lakarsantri, Surabayasebagai desa wisata adalah:

a) Sebagai Agrowisata sangatlah pas karena masyarakat di Desa Bendungan, Kelurahan Sumur Welut, Kecamatan Lakarsantri, Surabaya mayoritas adalah petani, sedangkan wisata yang ditawarkan dalam bentuk pariwisata desa (rural tourism) yang dikemas dalam bentuk education yang menawarkan proses kegiatan pertanian dengan melibatkan masyarakat petani sekitar. MenurutJolly danReynolds, agrowisata adalah suatubisnis yangdilakukanolehparapetaniyangbek erjadisektor

pertanianbagikesenangandanedukasip arwisatapengunjung(Andini,2013:104 ) .

b) Disamping menawarkan wisata agrowisata Desa Bendungan, Kelurahan Sumur Welut, Kecamatan
Lakarsantri, Surabaya juga mempunyai destinasi yang bisa ditawarkan sebagai lokasi wisata diperkotaan seperti Surabaya yaitu wisata air. Desa Bendungan, Kelurahan Sumur Welut, Kecamatan Lakarsantri, Surabaya mempunyai dua waduk yang cukup mewadai sebagai tempat alternatif sebagai wisata air.

c) Dan disamping dua destinasi wisata yang ditawarkan di Desa Bendungan, Kelurahan Sumur Welut, Kecamatan Lakarsantri, Surabaya juga mempunyai hutan yang masih terpelihara keasliannya dengan luas kurang lebih 1,5 hektar dan merupakan wisata yang mungkin tidak akan ditemui lagi di kota Surabaya.

d) Sedangkan wisata budaya yang ditawarkan di Desa Bendungan, Kelurahan Sumur Welut, Kecamatan Lakarsantri, Surabaya adalah bahwa masih kuat dan kentalnya budaya yang sampai sekarang dilakukan yang dikemas dengan judul "Tapak Jejak", yang bertujuan sebagai sedekah bumi dan pengingat asal muasal adanya Desa Bendungan, Kelurahan Sumur Welut, Kecamatan Lakarsantri, Surabaya.

FOTO 


\section{Pelaksanaan Program}

Kegiatan pengabdian

kepada masyarakat "Mengembangkan Potensi Desa dengan Peningkatan Kesehatan dan Kreativitas Masyarakat" di Desa Bendungan, Kelurahan Sumur Welut, Kecamatan Lakarsantri, Surabaya,yang diharapkan dengan kegiatan inin dapat meningkatkan partisipasi masyarakat sadar bahwa mereka punya daerah yang berpotensi sebagai destinasi pariwisata yang berimplikasi meningkatkan aspek ekonomi dan kesejahteraan masyarakat.

Pengabdian kepada masyarakat yang telah dilaksanakan menghasilkan beberapa rekomendasi yang telah disepakati antara masyarakat dan perangkat desa, meliputi:

a. Program Kesehatan

Penyuluhan dan pemeriksaan
kesehatan masyarakat di Desa
Bendungan, Kelurahan Sumur Welut,
Kecamatan Lakarsantri, Surabayaakan
dilaksanakan secara
berkesinambungan dan sesuai dengan
jadwal yang telah disepakati antara
salah satu STIKES di kota Surabaya
yang berkoordinasi dengan Puskemas
setempat yang selanjutnya akan
dilaksanakan pembuatan MoU antara
pihak desa dan STIKES.
Kesepakatan berkaitan dengan jadwal
memang perlu dilakukan karena

berkaitan dengan jadwal para petani dalam proses pengolahan lahan sawah yang mereka kelola yang terkadang tidak dapat dijadwalkan secara pasti.

Kesadaran akan lingkungan yang bersih, sosialisasi berkaitan dengan pemanfaatan sampah-sampah organik yang diolah menjadi pupuk organik. Disamping itu juga sudah di Desa Bendungan, Kelurahan Sumur Welut, Kecamatan Lakarsantri, Surabaya sudah disediakan oleh pihak kota Surabaya tempat pembuangan sampah sementara yang berada dipintu masuk desa Bendungan dan bagaimana cara perawatannya sehingga terus tampak bersih dan rapi.

b. Kreatifitas

Pelatihan guna menumbuhkan kreatifitas masyarakat di desaDesa Bendungan, Kelurahan Sumur Welut, Kecamatan Lakarsantri, Surabaya difokuskan pada pengembangan bagaimana proses pertanian, serta paska panenserta edukasi dan budaya sebagai rujukan dalam proses pengembangan potensi desa sebagai desa wisata. Pelaksanaan pelatihan dengan dilatarbelakangi oleh potensi di desa Bendungan yang berbasis pertanian dan sebagian besar penduduk juga berprofesi sebagai petani, sehingga dalam proses 
pelatihannya mudah dikembangkan oleh masyarakat desa Bendungan.

Beberapa pelatihan yang dilakukan adalah bagaimana mengemas proses produksi pertanian dalam bentuk edukasi yang bisa juga dilalukan oleh para pengunjung wisata contohnya cara bercocok tanam sayuran.

\section{RencanaTindakLanjut}

Agar berkelanjutan program pengabdian kepada masyarakat ini akan dilakukan pendampingan agar memotivasi partisipasi dan dukungan segenap komponen masyarakat dalam mendorong terwujudnya iklim yang kondusif bagi tumbuh dan berkembangnya kepariwisataan di Desa Bendungan, Kelurahan Sumur Welut, Kecamatan Lakarsantri, Surabaya. Kami berkeinginan melakukan pelatihan sadar wisata agar menumbuhkan kesadaran masyarakat desa siap untuk berperan sebagai tuan rumah dan memahami, mampu serta bersedia menjadikan Desa Bendungan, Kelurahan Sumur Welut, Kecamatan Lakarsantri, Surabaya sebagai desa wisata. 


\section{KESIMPULAN}

1. Desa Bendungan, Kelurahan Sumur Welut, Kecamatan Lakarsantri, Surabayamemiliki potensi sebagai desa wisata kota Surabaya. Pemetaan potensipotensi unggulan yang layak dikembangkan yaitu: agrowisata (wisata agro dan wisata edukasi), selain itu potensi wisata Hutan Kota dan budaya dan lainnya

2. Strategi perintisan dengan melakukan pelatihan mengenai sadar akan kesehatan dan menumbuhkan kreatifitas masyarakat desa sebagai penunjang obyek desa wisata

3. Implementasi strategi perintisan dengan melakukan budaya bersih dan sehat serta pelatihan untuk menumbuhkan kreatifitas masyarakat petani di Desa Bendungan, Kelurahan Sumur Welut, Kecamatan Lakarsantri, Surabaya sesuai dengan potensi yang ada.

\section{SARAN}

1. Desa Bendungan, Kelurahan Sumur Welut, Kecamatan Lakarsantri, Surabayaperlu membentuk kelembagaan wadah sebagai Pengelola Desa Wisatayang secara khusus melakukan pengelolaan Desa Wisata.

2. Secara berkelanjutan melakukan koordinasi yang lebih sinergis antara pihak Desa dalam hal ini Camat dan Lurah,
KetuaKelompok Tani dan masyarakat dalam pembangunan Desa Wisata.

3. Melakukan koordinasi dan bimbingan serta arahan kepada pemerintah kota Surabaya khususnya dinas pariwisata dalam mengembangkan potensi yang telah ada.

\section{UCAPAN TERIMA KASIH}

Dalam kesempatan ini tak lupa kami mengucapkan terimakasih kepada:

1. Universitas Wijaya Putra Surabaya dan Kelompok KKN 2-04

2. Ibu Lurah Sumur Welut, Ibu Sri Wahyoeningtyasih SE

3. Ketua STIKES RKZ Surabaya

4. Masyarakat Desa Bendungan, Kelurahan Sumur Welut, Kecamatan Lakarsantri, Surabaya.

\section{DAFTARPUSTAKA}

Andini, Nurulitha., dalam "Pengorganisasian Komunitas Dalam Pengembangan Agrowisata di Desa Wisata Studi Kasus: Desa Wisata Kembangarum, Kabupaten Sleman, Jurnal Perencanaan Wilayah dan Kota, Vol. 24 No. 3, Desember 2013

Juliantara, Dadang., 2003, Pembaharuan Desa, Bertumpu Pada Angka Terbawah, LapperaPustaka Utama, Yogyakarta

Kuncoro, Hendrie Ajie, dan Janianton Damanik, Jurnal Ilmu Sosial dan Ilmu Politik Volume 6 No.1Juli 2002

Kusumasari, Bevaola, dan Hempri Suyatna, dalam "Peningkatan Kapabilitas 
Pemasaran Pascabencana Bagi Perempuan Hunian Tetap Pager Jurang, Sleman, Yogyakarta", Jurnal Indonesian Journal of Community Engagement Vol. 01. No. 01, September 2015

Nadir, Sakinah., dalam "Otonomi Daerah dan Desentralisasi Desa: Menuju PemberdayaanMasyarakat Desa, Jurnal Politik Profetik Volume 1 Nomor 1 Tahun 2013

Widjajanti, Kesi, dalam "Model Pemberdayaan Masyarakat", Jurnal
Ekonomi Pembangunan Volume12, Nomor 1, Juni 2011

Zanibar, Zen., dalam "Desa: Pergulatan Mencari Jati Diri", Jurnal Konstitusi Volume 4, Nomor 1, Maret 2007

\section{Peraturan Perundang-undangan:}

- Undang-Undang Dasar 1945 (Pembukaan)

- Undang-Undang Nomor 36 Tahun 2009 tentang Kesehatan

- Undang-undang No.6 Tahun 2014 tentang Desa 
Daftar Gambar/Monggo dipilih utk melengkapi tulisan

Sak derenge matur Nuwu

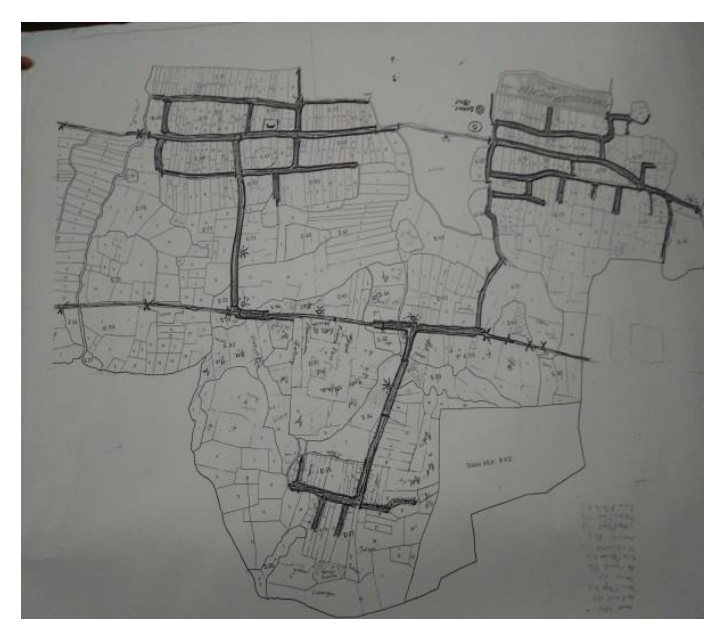

Peta Desa

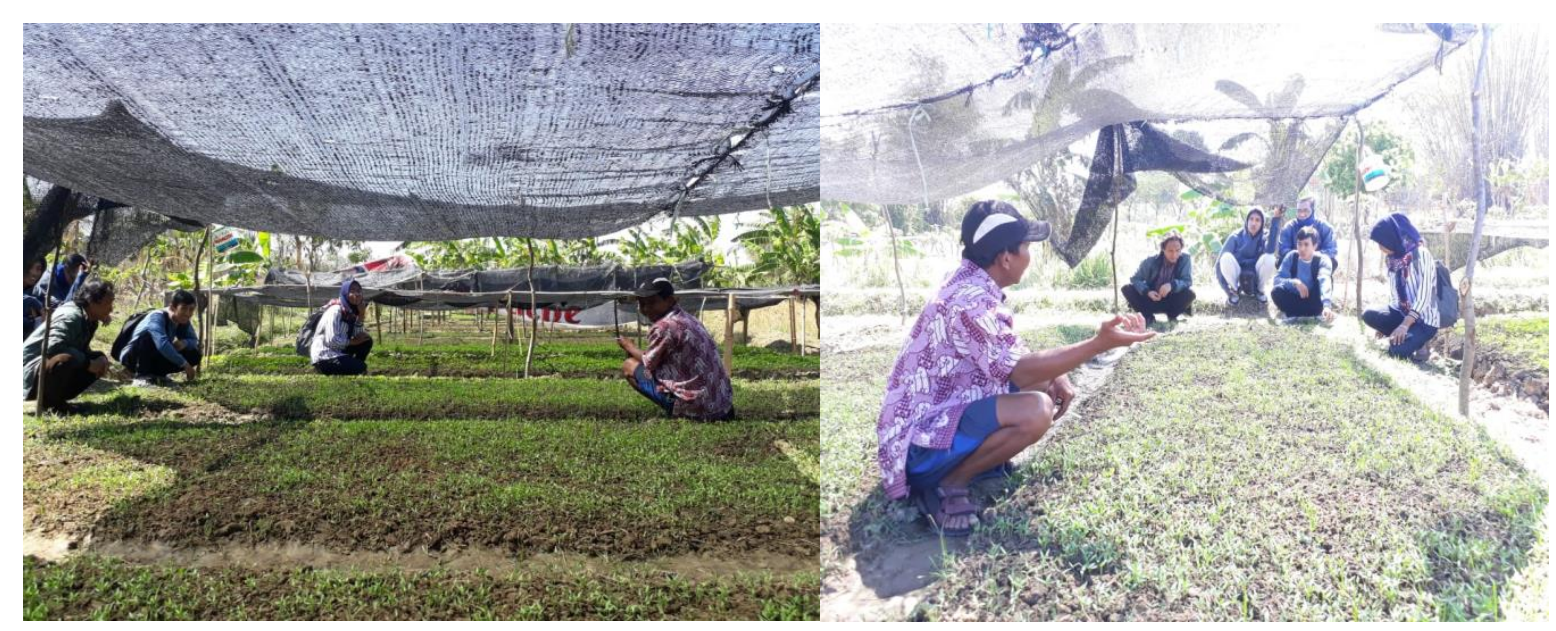

Penanaman Benih Cabe 


\section{|F|KM CSBR}

Prosiding PKM-CSR, Vol. 2 (2019)

e-ISSN: $2655-3570$

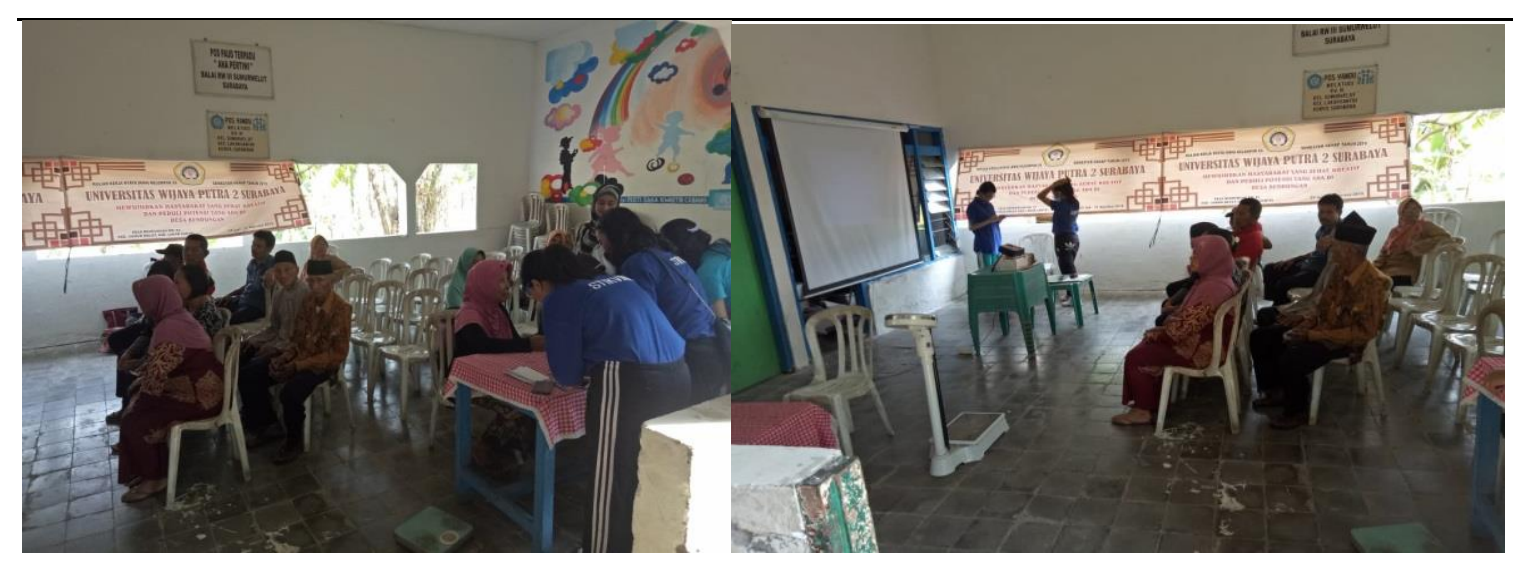

Sosialisasi Kesehatan
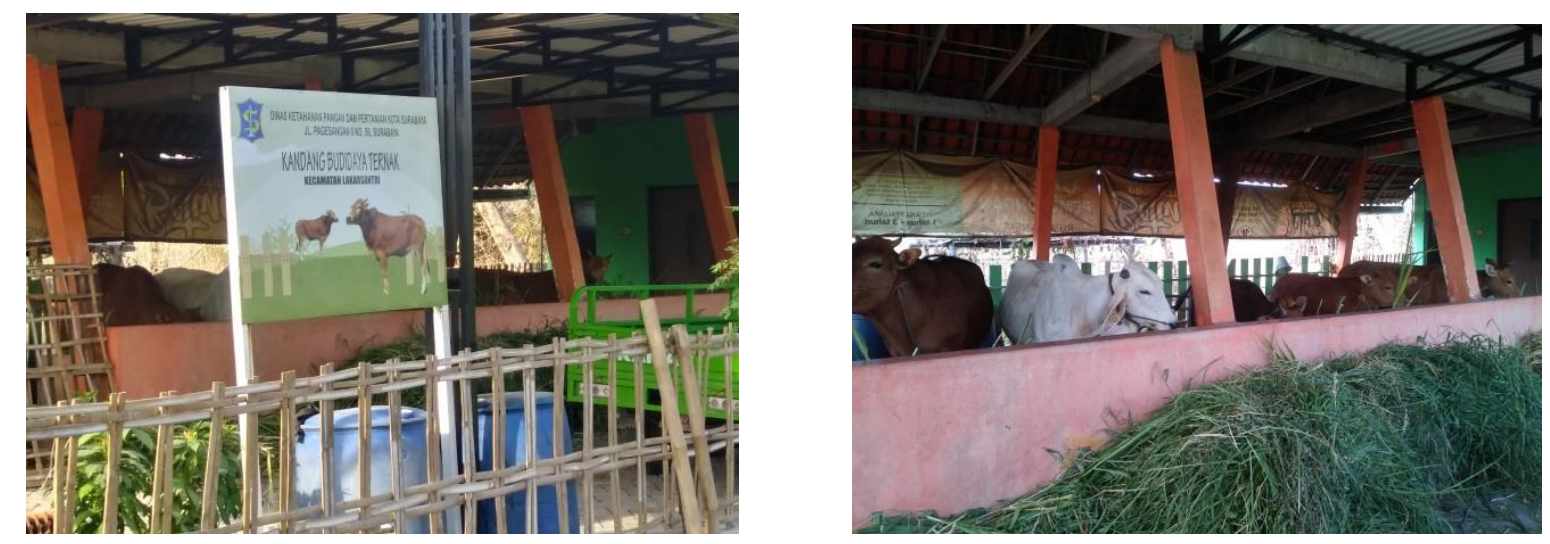

Budidaya Ternak
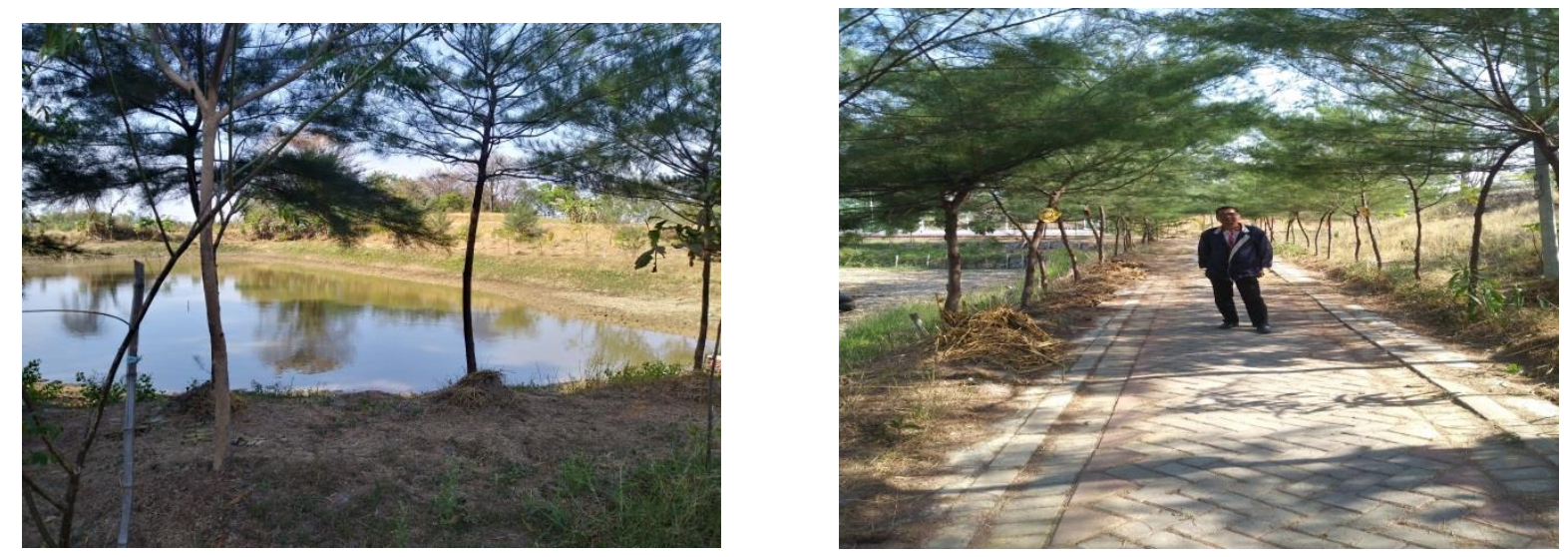

Kesehatan 535 

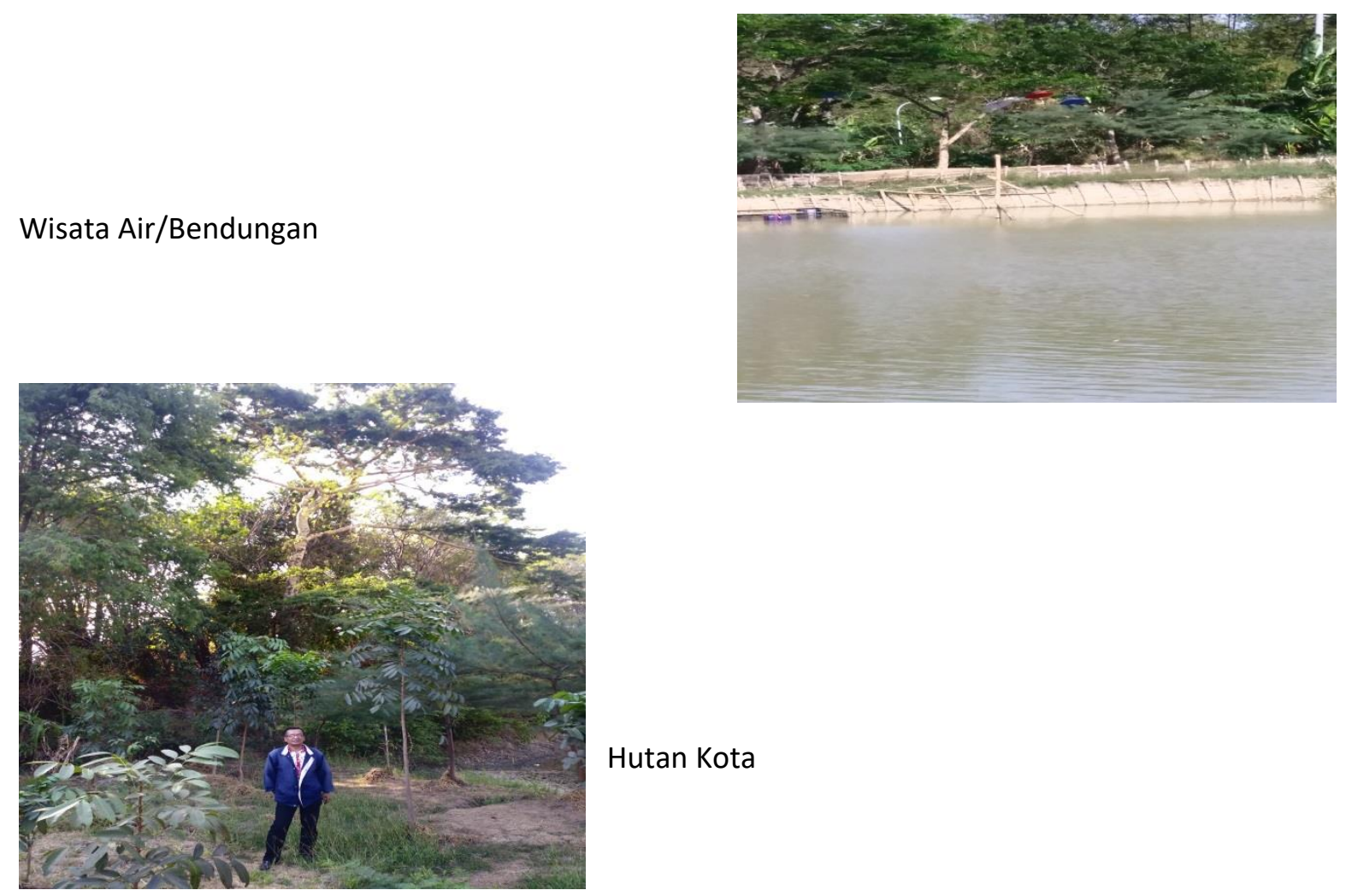

Hutan Kota 